\title{
Integration Study of Shanghai Basic Medical Insurance System for Urban and Rural Residents
}

\author{
Yuxia Zhu ${ }^{1} \&$ Yunlou Yan ${ }^{2}$ \\ ${ }^{1}$ School of Management, Shanghai University of Engineering Science, Shanghai, China \\ ${ }^{2}$ School of Social Science, Shanghai University of Engineering Science, Shanghai, China \\ Correspondence: Yuxia Zhu, School of Management, Shanghai University of Engineering Science, Long Teng Road \\ No.333, China. Tel: 86-153-1671-2231. E-mail: 1039890481@qq.com
}

Received: May 25, $2014 \quad$ Accepted: June 18, $2014 \quad$ Online Published: June 28, 2014

doi:10.5430/sass.v1n2p93 URL: http://dx.doi.org/10.5430/sass.v1n2p93

\begin{abstract}
At present, Shanghai has basically formed basic medical insurance system consisting of basic medical insurance for urban workers, basic medical insurance for urban residents, the new rural cooperative medical insurance, which covers urban employed population, the urban working population, rural population. Urban-rural system split and run independently, which is not conducive to social justice, thus narrow the gap between urban and rural areas and strengthen the integration of the system. In this paper, through the comparison of Shanghai's basic medical insurance for urban residents and new rural cooperative medical insurance in funding criteria and medical benefit level and introducing Jiaxing mode, Chengdu mode and Dongguan mode, thus put forward the integration solution of Shanghai's basic medical insurance system for urban and rural residents.
\end{abstract}

Keywords: Shanghai, basic medical insurance for urban residents, the new rural cooperative medical insurance, Integration

\section{Introduction}

November 2013-eighth plenary meeting of the Third Plenary has passed The Communist Party Central Committee's decision on deepening reform of several major issues, this document propose to integrate the basic old-age insurance system for urban and rural residents and the basic medical insurance system for urban and rural residents. Promote medical reform to the further develop and integrate the basic medical insurance system for urban and rural residents, which proposed in 2014 government work report. Promoting people-oriented new urbanization, which also mentioned in the report. More farmers shift to citizens, Therefore, the integration of urban and rural residents basic medical insurance system and the convergence of urban and rural medical relation are a trend.

At present, Shanghai has basically formed basic medical insurance system consisting of basic medical insurance for urban workers, basic medical insurance for urban residents, the new rural cooperative medical insurance, which covers urban employed population, the urban working population, rural population. Meanwhile, Shanghai is an international metropolis, high levels of economic development, integrate the basic medical insurance system for urban and rural residents, achieve urban and rural residents insurance benefits equally, which is feasible.

\section{Necessity of Urban and Rural Residents Basic Medical Insurance System Integration}

Firstly, our country implements urban-rural dual economic structure in a long time. It depends urban-rural dual medical security system, so does Shanghai. It violates the principle of urban and rural residents enjoy the right to health in equality. Basic medical insurance for urban residents and the new rural cooperative medical insurance of shanghai are run independently. Rural residents enjoy lower level of medical security. It violates the principle of social fairness. Therefore, the integration of urban and rural residents basic medical insurance system is the inevitable requirement for achieve social fairness.

Secondly, Shanghai has entered the development stage overall in which industry promotes agriculture, urban with rural. It is an important period of new pattern of urban and rural economic and social integration. Integration of urban 
and rural development requires the integration of urban and rural residents basic medical insurance system. Meanwhile, the aging population of shanghai has developed rapidly. It is one of the area in which the aging population is the most prominent issue. As of December 31.2013, in the 14.3234 million census register population of Shanghai ,elderly people aged 60 and over has reached 3.8762 million, accounting for $27.1 \%$ of total population. It means that there is an old man of every four census register population. Shanghai has entered into a deeper aging society. Therefore the integration of urban and rural residents basic medical insurance system is to alleviate the pressure of population ageing, and It is the urgent requirement of the sustainable development of medical insurance system. At the last, two systems operate dividedly, which leads administrative costs to increase and affects the administrative efficiency, so the integration of urban and rural residents basic medical insurance system is the inevitable requirement of reducing administrative costs.

\section{The Basic Situation of Basic Medical Insurance for Urban Residents and the New Rural Cooperative Medical Insurance of Shanghai}

\subsection{The Basic Medical Insurance System for Urban Residents}

Shanghai trial implementation measures for the basic medical insurance for urban residents formally implemented in 2008, marking the establishment of the basic medical insurance system for urban residents in Shanghai. Medical insurance system for urban residents in Shanghai, expanding coverage, basically covering the urban non-employed residents. It integrated by urban insecurity elderly senior citizens basic medical security system urban workers aged wills basic medical insurance. Schoolchildren and infant hospitalization, outpatient illness basic medical security system、 common colleges and universities student medical security system. Since 2008, the medical insurance system for urban residents in Shanghai formally implemented, the number of insured population is increasing. In 2011, the number of urban residents basic medical insurance (including ordinary university students) reached 2.4975 million; In 2012, it has reached 2.6259 million people.

\subsection{The New Rural Cooperative Medical Insurance System}

Shanghai rural cooperative medical system started in 1958, it is one of the few insist cooperative medical system unbroken provinces. There are 17 counties in Shanghai, including nine counties to carry out the new rural cooperative medical insurance, In suburban towns, villages of Shanghai, the new rural cooperative medical insurance coverage continues to maintain $100 \%$, farmer participation rate is $98.9 \%$, basically covered all. In 2010 , the new rural cooperative medical insurance of Shanghai has put forward some measures, continuously improving the level of protection and continuing to make breakthroughs. In 2011, per capita raised funds of Shanghai the new rural cooperative medical insurance amounted to 987 yuan, compare with 306 yuan in 2005 , improving $222 \%$. Shanghai is the highest raise funds region. All levels of financial support funds totaled 713 million yuan of the new rural cooperative medical insurance in Shanghai, 2010, as individual farmers pay 2.67 times. Thereby, the "new rural cooperative" security level is greatly improved. Real-time reimbursement of costs, which reduces medical burden. Realize interregional for medical treatment, which provides convenience for farmers.

\section{The Comparison Basic Medical Insurance for Urban Residents with the New Rural Cooperative Medical Insurance in Shanghai}

\subsection{The Contribution Rate Comparison}

The way of financing of Shanghai basic medical insurance for urban residents is combine individual payment and government subsidy. The multi-channel financial mechanism of the new rural cooperative medical insurance fund is combine individual contributions, collective support with financial subsidy, primarily by individual contributions and government subsidies co-financing, fully embodies the medical insurance fund raising is the common responsibility of the individual and the government. In 2013, fund raising standard of Shanghai's basic medical insurance for urban residents is rising, funding levels is also rising. Table 1 shows that Shanghai residents of different ages insured different medical funding standard. More inclined to finance subsidy for the elderly and minors, up to $89.7 \%$. At the same time, the insured family members in the city to enjoy the minimum living guarantee for urban residents, and the town's senior citizens within the meaning of this approach, individual contributions some workers aged survivors, towns and other severely disabled people, support by the government to provide subsidies, while the 19-59 year-old financial subsidies for urban residents only about $60 \%$. 
Table 1. 2013 Shanghai residents of all ages insured object Medical funding criteria (Unit: RMB)

\begin{tabular}{llllll}
\hline Insured object & $\begin{array}{l}\text { Total } \\
\text { funding } \\
\text { criteria }\end{array}$ & $\begin{array}{l}\text { Individual } \\
\text { contributions }\end{array}$ & $\begin{array}{l}\text { The proportion } \\
\text { of } \begin{array}{c}\text { individual } \\
\text { contributions }\end{array}\end{array}$ & $\begin{array}{l}\text { Government } \\
\text { grants }\end{array}$ & $\begin{array}{l}\text { The } \\
\text { proportion of } \\
\text { government } \\
\text { grants }\end{array}$ \\
\hline Over 70 years & 3300 & 340 & $10.3 \%$ & 2960 & $89.7 \%$ \\
\cline { 3 - 6 } & $50-69$ & 500 & $15.2 \%$ & 2800 & $84.8 \%$ \\
\hline $\begin{array}{l}\text { 19-59 } \\
\text { Children, }\end{array}$ & 7700 & 680 & $40 \%$ & 1020 & $60 \%$ \\
\hline $\begin{array}{l}\text { university } \\
\text { students }\end{array}$ & 750 & 90 & $12 \%$ & 660 & $88 \%$ \\
\hline
\end{tabular}

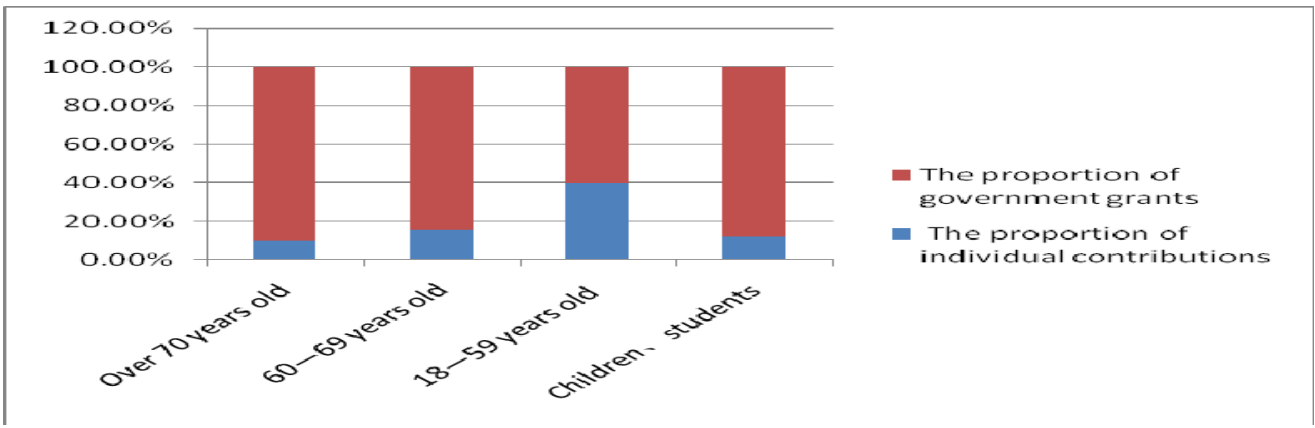

Figure 1. 2013 Medicare financing for urban residents in Shanghai government subsidies case

The new rural cooperative medical insurance of Shanghai is implemented individual contributions, collective support and financial assistance multi-channel funding mechanism. At present, the new rural cooperative medical insurance of Shanghai is try to do real district (county) level co-ordination. Every suburban counties varies in funding criteria. Funding criteria are determined by the suburban counties based on the state and city to determine funding requirements and integrated area-based revenue and expenditure for the year. According to statistics, Shanghai Pudong New Area, Jiading District, Songjiang District, Qingpu District, Jinshan, Fengxian District and Chongming County to achieve district-level co-ordination. These counties have issued notice about their own funding criteria of the new rural cooperative medical insurance. Shanghai now has done real district (county) level co-ordination funding criteria are shown in Table 2. As seen from Figure 2, in Shanghai financial assistance of the new rural cooperative medical insurance between $40.9 \%$ and $83.7 \%$, while rural residents, five households, the elderly farmers and individuals with disabilities pay part of the full fiscal subsidies.

Table 2. At present, the funding criteria of the new rural cooperative medical insurance where achieves district-level co-ordination

\begin{tabular}{|c|c|c|c|c|c|c|c|c|}
\hline \multirow{2}{*}{$\begin{array}{l}\text { Agricultural } \\
\text { counties } \\
\text { (District-level } \\
\text { co-ordination) }\end{array}$} & \multirow{2}{*}{$\begin{array}{l}\text { Per } \\
\text { capital } \\
\text { fundin } \\
\mathrm{g}\end{array}$} & \multirow{2}{*}{$\begin{array}{l}\text { Individual } \\
\text { contributio } \\
\text { ns }\end{array}$} & \multicolumn{5}{|c|}{ Government } & \multirow{2}{*}{$\begin{array}{l}\text { Village } \\
\text { collective } \\
\text { enterprises }\end{array}$} \\
\hline & & & $\begin{array}{l}\text { The } \\
\text { central } \\
\text { governme } \\
\text { nt }\end{array}$ & $\begin{array}{l}\text { Municipa } \\
1 \\
\text { governm } \\
\text { ent }\end{array}$ & $\begin{array}{l}\text { District } \\
\text { (county) } \\
\text { governm } \\
\text { ent }\end{array}$ & $\begin{array}{l}\text { Town } \\
\text { governmen } \\
\mathrm{t}\end{array}$ & Ttotal & \\
\hline $\begin{array}{l}\text { Pudong New } \\
\text { Area }\end{array}$ & 1500 & 320 & -- & -- & -- & -- & 1080 & 100 \\
\hline $\begin{array}{l}\text { Jiading } \\
\text { District }\end{array}$ & 1216 & 350 & 87 & 94 & 158 & 158 & 497 & 100 \\
\hline $\begin{array}{l}\text { Songjiang } \\
\text { District }\end{array}$ & -- & 360 & -- & -- & -- & -- & -- & -- \\
\hline
\end{tabular}




\begin{tabular}{lllllllll}
\hline $\begin{array}{l}\text { Qingpu } \\
\text { District }\end{array}$ & -- & 330 & -- & -- & -- & -- & -- & -- \\
\hline $\begin{array}{l}\text { Jinshan } \\
\text { District }\end{array}$ & 2030 & 310 & -- & 120 & 800 & 800 & 1720 & -- \\
\hline $\begin{array}{l}\text { Fengxian } \\
\text { District }\end{array}$ & 1600 & 320 & -- & -- & 580 & 580 & 1160 & -- \\
\hline $\begin{array}{l}\text { Chongming } \\
\text { County }\end{array}$ & 1780 & 270 & -- & 300 & 710 & 480 & 1490 & 20 \\
\hline
\end{tabular}

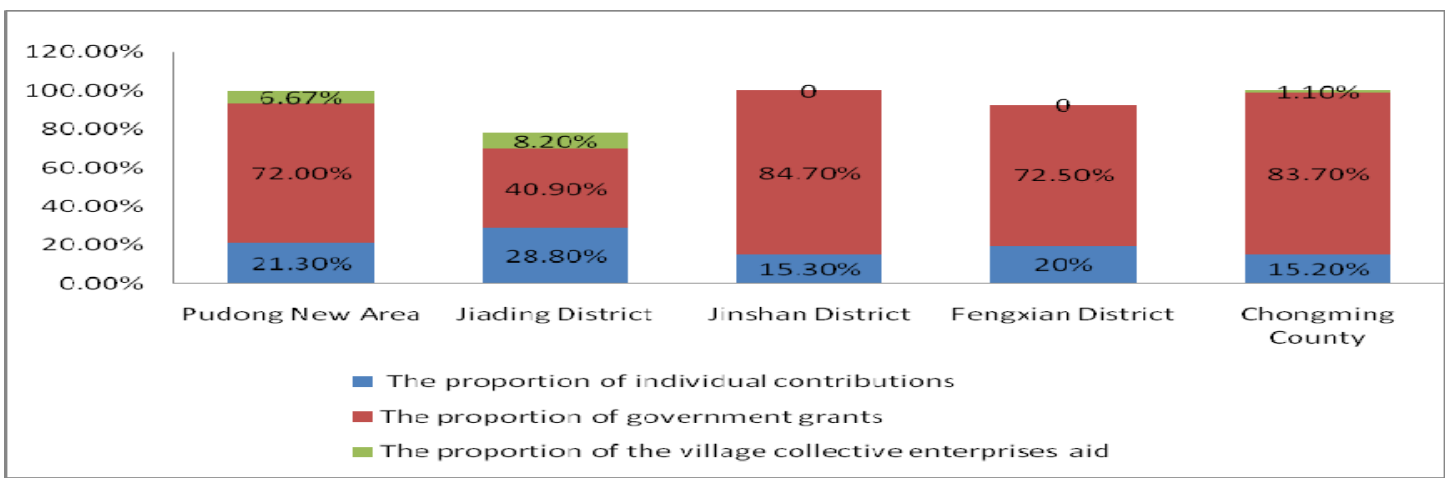

Figure 2. At present, the funding criteria of the new rural cooperative medical insurance where achieves district-level co-ordination

Table 2 and Figure 2 comparison, Medicare funding of Shanghai residents over the age of 70 insured financial assistance is about eight times the individual contributions, 60-69 years old insured financial assistance is about 5 times the individual contributions, 15-59 years old of the insured person financial assistance is about 1.5 times the individual contributions, children and student financial aid is about seven times the individual contributions, we can see that Shanghai residents health insurance law for financial assistance based on risk of disease groups varies, the elderly, children and students receive financial aid is relatively high. But the financial aid of Shanghai's the new rural cooperative medical insurance funding is about 3-5 times the individual contributions. At the same time, in the overall area, individual contributions and The new rural cooperative medical insurance Financial subsidy are the same, unlike the Medicare population ages divided implement different funding criteria, without taking into account the affordability of the elderly.

\subsection{The Level of Health Insurance Benefits Paid Comparison}

The fairness issue of the two systems is mainly reflected in health insurance payment, so it is necessary to compare health care treatment of two systems. Since the new rural cooperative medical insurance belongs to district-level co-ordination, so choose two representative districts for comparison.

Table 3. Shanghai city residents medical treatment standard

\begin{tabular}{|c|c|c|c|c|}
\hline \multirow[t]{2}{*}{$\begin{array}{l}\text { Categories of } \\
\text { personnel }\end{array}$} & \multicolumn{2}{|c|}{$\begin{array}{l}\text { Hospitalizations (including emergency observation } \\
\text { room, in hospital under observation) }\end{array}$} & \multicolumn{2}{|c|}{$\begin{array}{l}\text { Emergency Department } \\
\text { (including family bed) }\end{array}$} \\
\hline & Starting line & More than pay line section & $\begin{array}{l}\text { Starting } \\
\text { line }\end{array}$ & $\begin{array}{l}\text { More than starting } \\
\text { line section }\end{array}$ \\
\hline $\begin{array}{l}\text { Schoolchildren } \\
\text { and infants }\end{array}$ & & $\begin{array}{l}\text { In the community health service } \\
\text { centers (or a medical institution) }\end{array}$ & 300 & $\begin{array}{lr}\text { In the community } \\
\text { health }\end{array}$ \\
\hline $\begin{array}{l}\text { More than } 18 \\
\text { years old but } \\
\text { less than } 60 \\
\text { years old }\end{array}$ & One: 50 yuan & $\begin{array}{l}\text { to pay } 80 \% \text { of the hospital; } \\
\text { Pay } 70 \% \text { of hospitalizations in the } \\
\text { secondary medical institutions; } \\
\text { Pay } 60 \% \text { of hospital tertiary care } \\
\text { institutions }\end{array}$ & 1000 & $\begin{array}{l}\text { centers (or a } \\
\text { medical institution) } \\
\text { Outpatient } \\
\text { emergency, the } \\
\text { payment of } 65 \% \text {; }\end{array}$ \\
\hline
\end{tabular}




\begin{tabular}{|c|c|c|c|c|}
\hline $\begin{array}{l}\text { Towns severely } \\
\text { disabled persons }\end{array}$ & \multirow{2}{*}{$\begin{array}{l}\text { Two: } \$ 100 \\
\text { Three: } 300 \text { yuan }\end{array}$} & \multirow{2}{*}{$\begin{array}{l}\text { In the community health service } \\
\text { centers (or a medical institution) } \\
\text { to pay } 90 \% \text { of the hospital; } \\
\text { Pay } 80 \% \text { of hospital secondary } \\
\text { care; } \\
\text { Pay } 70 \% \text { of hospitalizations in } \\
\text { tertiary care institutions }\end{array}$} & \multirow[b]{2}{*}{300} & \multirow{2}{*}{$\begin{array}{l}\text { In secondary care } \\
\text { outpatient } \\
\text { emergency, the } \\
\text { payment of } 55 \% \text {; } \\
\text { In three outpatient } \\
\text { emergency medical } \\
\text { institution, the } \\
\text { payment of } 50 \%\end{array}$} \\
\hline $\begin{array}{l}60 \text { years old and } \\
\text { above }\end{array}$ & & & & \\
\hline
\end{tabular}

Table 4. Songjiang District

\begin{tabular}{llllllc}
\hline $\begin{array}{l}\text { Compensation } \\
\text { ratio of medical } \\
\text { institutions at all } \\
\text { levels }\end{array}$ & $\begin{array}{l}\text { Village } \\
\text { health }\end{array}$ & $\begin{array}{l}\text { Community } \\
\text { Health } \\
\text { Center }\end{array}$ & $\begin{array}{l}\text { Two } \\
\text { medical } \\
\text { institutions }\end{array}$ & $\begin{array}{l}\text { Three } \\
\text { medical } \\
\text { institutions }\end{array}$ & $\begin{array}{l}\text { Conceited } \\
\text { segment }\end{array}$ & Cap line \\
\hline $\begin{array}{l}\text { Emergency } \\
\text { Department }\end{array}$ & $80 \%$ & $70 \%$ & $60 \%$ & $50 \%$ & 300 & 5000 \\
\hline Be hospitalized & - & $80 \%$ & $75 \%$ & $50 \%$ & - & 120000 \\
\hline
\end{tabular}

Table 5. Qingpu District

\begin{tabular}{|c|c|c|c|c|c|c|}
\hline $\begin{array}{l}\text { Compensation } \\
\text { ratio of } \\
\text { medical } \\
\text { institutions at } \\
\text { all levels }\end{array}$ & $\begin{array}{l}\text { Village } \\
\text { health }\end{array}$ & $\begin{array}{l}\text { Community } \\
\text { Health } \\
\text { Center }\end{array}$ & $\begin{array}{l}\text { Two } \\
\text { medical } \\
\text { institutions }\end{array}$ & $\begin{array}{l}\text { Three } \\
\text { medical } \\
\text { institutions }\end{array}$ & $\begin{array}{l}\text { Conceited } \\
\text { segment }\end{array}$ & Cap line \\
\hline $\begin{array}{l}\text { General } \\
\text { emergency } \\
\text { door }\end{array}$ & $80 \%$ & $70 \%$ & $60 \%$ & $50 \%$ & 200 & 5000 \\
\hline $\begin{array}{l}\text { Hospital } \\
\text { (including } \\
\text { outpatient } \\
\text { illness) }\end{array}$ & -- & $80 \%$ & $75 \%$ & $50 \%$ & -- & $\begin{array}{l}\text { Rural area } \\
\text { residents last } \\
\text { year household } \\
\text { disposable } \\
\text { income } 6 \text { times }\end{array}$ \\
\hline
\end{tabular}

In term of starting line standard, basic medical insurance for urban residents of Shanghai has set up the starting line in the hospital and emergency department, and the new rural cooperative medical insurance has set up the starting line only in the emergency department. By comparison, the starting line of the new rural cooperative medical insurance is more relaxed, meanwhile the starting line standard is relatively low. In term of the proportion of reimbursement, reimbursement ratio of two systems are equivalent.

\section{Shanghai Basic Medical Insurance for Urban Residents and the New Rural Cooperative Medical Insurance Integration Obstacles}

As can be seen by comparing these two systems, contribution rate and health insurance benefits are equivalent or less, so there is the possibility of fully integrating the two systems, but the obstacles of integration the two systems in Shanghai still exist in reality.

First of all, the overall level of the two systems differ in Shanghai hindered the integration of the two systems. Basic medical insurance for urban residents of Shanghai is municipal co-ordination, co-ordination level higher, stronger ability to resist risk, the new rural cooperative medical insurance of Shanghai implement district co-ordinate, overall level is relatively low. Because of different co-ordination level, it is difficult to unity fund, hindering the integration of the two systems; Secondly, two systems are managed by two different departments, basic medical insurance for urban residents is managed by the Department of Human Resources and Social Security, and the new rural cooperative is managed by the health department, different lead management system administration, different 
handling procedures, different information systems, not only a waste of resources and cost, but also prevent the integration of the two systems. Finally once the two systems integration, according to "high principle", appearing the health insurance fund gap, determine the main responsibility fund gap, lack of transparency effect on municipal finance fund gap is the biggest obstacle to the integration of the two system.

\section{China's Basic Medical Insurance for Urban Residents and the New Rural Cooperative Medical Insurance Integration Regional Experience}

\subsection{Jiaxing Mode}

In JiaXing, before the medical security system for urban residents has not been established, According to the concept of urban and rural, based on the new rural cooperative medical insurance, the non-working urban residents will be also included in the scope of the insured, so that called the informal employment health system "cooperative medical insurance system for urban and rural residents" two people of the same system, continuous integration, expanding the scope of the insured, the progressively realize "eight unity", including the regulatory agencies, financing, funding criteria, compensation levels, starting line, settlement approach, the fund management. The integration of the two systems continue to develop in depth. Features of Jiaxing models in expanding the scope of NCMS, put the residents into the formation of the new rural cooperative, unified management by the health department, a fund fully integrated mode.

\subsection{Chengdu Mode}

Chengdu was originally established seven different health insurance system based on seven different groups, showing system "fragmented" state. According to the concept of urban and rural, the medical insurance system for urban residents, the new rural cooperative medical care and basic medical insurance for college students merge into urban and rural residents basic medical insurance system. The characteristics of Chengdu model integrate the new rural cooperative medical insurance into the new rural cooperative medical insurance. The residents basic medical insurance system for urban and rural residents is managed by the social security institutions, the health insurance agencies which under social security institutions, meanwhile set up two grades in terms of funding criteria, linked with treatment, pay more for much, which fully take into account the differences in economic levels.

\subsection{Dongguan Mode}

Dongguan has broken workers domicile, urban and rural residents in household registration and occupation three boundaries, which achieves the integration of urban and rural health care system, the health care system unified, payment standard unified, fund transfers unified, management services unified.

\section{The Shanghai Urban and Rural Residents Basic Medical Insurance System Integration}

In Shanghai, the basic medical insurance system was originally presented fragmented state, under the guidance of the concept of urban and rural integration, continuous integration system, forming the basic medical insurance system for workers, the basic medical insurance system for urban residents and the new rural cooperative medical insurance system, three systems operate independently, so the integration of urban and rural basic medical insurance system can not be done overnight, it should be phased step by step.

The first step is to improve the overall level of the new rural cooperative medical system, At present, Shanghai basic medical insurance for urban residents implements the municipal co-ordination, but the overall level of new rural cooperative medical system only stay in the district (county) level. The new rural cooperative medical insurance system of the suburban counties is not uniform. Payment standard and benefits are not uniform, the new rural cooperative fund only transfers inside agriculture-related suburban counties, Freemasons weak, fund of two systems operate independently, which hinders system integration, through setting up the municipal health insurance payments, as an interim step to improve the overall level of the new rural cooperative medical system, and ultimately municipal co-ordination.

The second step to unify administrative and insurance regulatory agencies of the two systems. Currently, Shanghai basic medical insurance for urban residents is in charge of human resources and social security department, but the new rural cooperative medical system is in charge of the hygiene department, managers, management practices, management procedures of two systems are not the same, which causes a waste of manpower, material and financial resources, so the two systems should be unified authority as soon as possible. The integration system is in charge of 
human resources and social security department, supervising by the health department. Meanwhile uniform computer information systems, which achieves information sharing.

The third step on the basis of previous work, integrated the two systems into the basic medical insurance system for urban and rural residents, comprehensively covering urban and rural residents, achieving a unified management approach, unified handling processes, unified information system, medical institutions and unity " three directories ", modeling Chengdu mode on the funding criteria, setting up two or more grades, and linked to treatment, pay more for much. The base pay is disposable income of urban residents and the net income of rural residents, adequately taking the differences in economic levels between urban and rural areas into account.

Throughout these steps the fiscal responsibility of the government reveal all the details, it is precisely because of government promote and financial support, the pilot areas successfully complete the system integration, the urban and rural residents basic medical insurance system integration means uniform funding standards and health care benefit, the benefit must follow on the high principle, it leads fund gap, Therefore strengthen the government's responsibility to the fund raising and payment, further increasing the government financial support, establish clear municipal, district (county) level and township level three levels of government fiscal responsibility sharing mechanism .

\section{References}

2013 Shanghai Statistical Yearbook.

2014 annual basic medical insurance for urban residents in Shanghai Policy Questions.

2014 Implementation Opinions Songjiang District Rural Cooperative Medical Financing and Compensation.

2014 new rural cooperative medical system implementation details Qingpu District.

LingShuai Yan, \& ZhongWu. Beijing, Shanghai, Guangzhou urban residents basic medical insurance system for comparison. Health Economics Research.

Qin Shen, Zhongwei Yu, \& Hao Hu. Jiaxing urban and rural medical insurance system main approach. Chinese Health Policy Research.

Wei Xing. Urban and rural residents in the medicare system integration practical exploration and reform proposals. Chinese Economic Herald.

Weishu Ma, \& Ning He. Comparative analysis of urban and rural medical insurance system mode. Theory and Modern.

Wenmei Li. Can three kinds of health insurance integrate into one. Employment and Social Security.

Ying Huang, Jingwen Huang, \& Yunqi Guo. Comparing urban and rural medical security system typical pattern Taking fangzi district, Chengdu and Dongguan City, for example, the legal system and society.

Zuojun Chen. Thinking of urban and rural medical security system. Macroeconomic Management. 